\title{
UPAYA MENINGKATKAN KEPERCAYAAN DIRI MELALUI LAYANAN BIMBINGAN KELOMPOK TEKNIK KONSELING BEHAVIOR PADA PESERTA DIDIK DI SMP NEGERI 10 PONTIANAK
}

\author{
Endah Fitriani \\ SMP Negeri 10 Pontianak \\ Jl. W.R. Supratman Benua Melayu Darat Kota Pontianak 78243 Telepon (0561) 743018 \\ Alamat e-mail: fitrianiendah@yahoo.co.id
}

\begin{abstract}
Abstrak
Jenis penelitian yang digunakan dalam penelitian ini adalah penelitian tindakan kelas dengan dua siklus tindakan. Sampel dalam penelitian ini adalah 10 orang peserta didik yang mempunyai kepercayaan diri sedang dan rendah. Hasil penelitian yang diperoleh, sebelum mendapatkan layanan bimbingan kelompok peserta didik yang mempunyai kepercayaan diri dengan presentase sedang $68,75 \%$, peserta didik dengan kepercayaan diri dengan presentase rendah $53,75 \%$. Setelah diberikan layanan bimbingan kelompok pada siklus 1, 8 orang peserta didik dengan kepercayaan diri sedang mengalami peningkatan dari 70\% - 72,75\% masuk dalam presentase kategori tinggi dan dua orang peserta didik presentase kepercayaan diri rendah bertambah 67,5\%-68,78\% masuk dalam kategori presentase sedang. Sedangkan pada siklus 2 , peserta didik dengan presentase kepercayaan diri sedang bertambah $83,75 \%$ masuk dalam kategori presentase tinggi dan peserta didik dengan kepercayaan diri rendah bertambah 76,25\% masuk dalam kategori presentase tinggi sehingga pada siklus 2 skala kepercayaan diri untuk 10 orang peserta didik masuk dalam kategori tinggi.
\end{abstract}

Kata Kunci: kepercayaan diri; layanan bimbingan kelompok; teknik behavior;

\begin{abstract}
The type of research used in this study is a classroom action research with two cycles of action. The sample in this study are 10 students who have low and moderate confidence. The results obtained, before getting the guidance services group of learners who have confidence with the percentage is $68.75 \%$, learners with confidence with a low percentage of $53.75 \%$. After being given group counseling service on cycle 1, 8 students with self confidence are experiencing an increase from $70 \%-72.75 \%$ entry in the percentage of high category and two students of low percentage of confidence increased by $67.5 \%-68.78 \%$ Entered in the category of moderate percentage. While in cycle 2, learners with the percentage of self confidence is increasing $83.75 \%$ into the category of high percentage and learners with low self-confidence increased $76.25 \%$ into the category of high percentage so that the cycle 2 scale of confidence for 10 participants entered into high category.
\end{abstract}

Keywords: confidence; group guidance service; behavior technique;

\section{PENDAHULUAN}

Bimbingan dan Konseling merupakan salah satu komponen penting dalam dunia pendidikan. Di laksanakannya layanan bimbingan dan konseling disekolah bukan karena adanya landasan hukum, namun yang lebih penting adalah kesadaran atau komitmen untuk memfasilitasi peserta didik agar mampu mengembangkan 
potensi dirinya. Peserta didik adalah individu yang sedang mengalami masa perkembangan, yaitu berkembang kearah kematangan dan kemandirian. Dalam hal inilah peserta didik banyak membutuhkan bimbingan untuk memperluas pengetahuan dan wawasan tentang dirinya dan lingkungan.

Pendidikan sangat penting dalam kehidupan sehari-hari, saat ini bangsa Indonesia berupaya meningkatkan mutu pendidikan dalam menghadapi perkembangan zaman. Dunia pendidikan diharapkan mampu mewujudkan cita-cita bangsa dan tujuan pendidikan nasional. Tujuan pendidikan nasional tercantum dalam Undang-undang Republik Indonesia Nomor 20 Tahun 2003 bab II pasal 3 yaitu mengembangkan kemampuan dan membentuk watak serta peradapan bangsa yang bermartabat dalam rangka mencerdaskan kehidupan bangsa, bertujuan untuk berkembangnya potensi seseorang tidak terwujud begitu saja apabila tidak di upayakan dan seberapa jauh individu tersebut mengupayakan sehingga bisa mewujudkan potensinya menjadi aktual dan terwujud dalam sikap kepribadiannya.

Hal ini dapat diperoleh apabila peserta didik memiliki rasa percaya diri, sehingga dapat meningkatkan perkembangannya baik oleh dirinya sendiri maupun lingkungan yang akan membantu pencapaiannya, salah satunya adalah dari lingkungan sekolah. Rasa percaya diri merupakan sikap mental optimisme dari kesanggupan anak terhadap kemampuan diri untuk menyelesaikan segala sesuatu dan kemampuan diri untuk melakukan penyesuaian diri pada situasi yang dihadapi (Surya, 2007:56). Menurut Anita (2003:4) menjelaskan bahwa kepercayaan diri merupakan salah satu faktor seseorang untuk dapat mempertimbangkan dan membuat keputusan sendiri. Santrock (2003:336) mendefinisikan kepercayaan diri merupakan sebuah dimensi yang menyeluruh dari diri seseorang sehingga seseorang dapat melihat gambaran positif dari diri individu.

Berdasarkan hasil wawancara dengan guru bidang studi tanggal 5 Oktober 2016 mengatakan bahwa jika dalam diskusi pada kelas VII E tidak begitu aktif, banyak peserta yang pasif, saya menunggu untuk peserta didik inisiatif sendiri untuk mengangkat tangan bertanya atau memberikan pendapat akan tetapi hanya beberapa peserta didik saja yang berani. Hasil pengamatan di SMP Negeri 10 di kelas VII E gejala yang diperoleh yaitu (1) peserta didik tidak berani mengajukan 
pertanyaan atau pendapat kepada guru, (2) tidak bersedia tampil di depan kelas, (3) berbicara gugup, (4) menghindarkan diri ketika akan di tanya oleh guru. Hal ini diperkuat dengan perilaku peserta didik ; tidak mau maju kedepan kelas, tidak berani tampil bila berhadapan dengan orang banyak, dan tidak mau mengajukan pendapatnya di dalam kelompok. Selain itu di perkuat dengan wawancara guru mengatakan bahwa peserta didik masih merasa malu untuk maju ke depan kelas mungkin dikarenakan peralihan dari SD ke SMP dan ada rasa takut salah.

Perilaku tidak percaya diri tersebut harus di tangani, agar peserta didik dapat meningkatkan rasa percaya dirinya. Alternatif bantuan yang dapat diberikan untuk membantu meningkatkan percaya diri peserta didik menggunakan bimbingan kelompok dengan teknik behavior yaitu mengubah perilaku peserta didik untuk bisa lebih percaya diri.

Menurut Prayitno (1995:61) layanan bimbingan kelompok adalah suatu layanan bimbingan yang diberikan kepada peserta didik secara bersama-sama atau kelompok agar kelompok itu menjadi besar, kuat dan mandiri. Dalam layanan tersebut para peserta didik dapat diajak untuk bersama-sama mengemukakan pendapat tentang sesuatu dan membuat topik - topik penting mengembangkan nilainilai tentang hal tersebut dan mengembangkan langkah-langkah bersama untuk menangani permasalahan yang dibahas dalam kelompok (Sukardi, 2000:48).

Dengan menggunakan layanan bimbingan kelompok dapat menolong individu untuk dapat memahami bahwa orang lain ternyata mempunyai kebutuhankebutuhan dan masalah-masalah yang sama berhubungan dengan aspek kepercayaan diri peserta didik dalam proses pembelajaran. Dalam penelitian ini, peneliti menggunakan teknik pendekatan behavior dengan teknik pengkondisian operan.

Pengkondisian operan merupakan salah satu teknik dalam terapi behavior, Skinner memusatkan pada hubungan tingkah laku dan konsekuensinya. Pengkondisian operan merupakan teknik yang menggunakan konsekuensi menyenangkan dan tidak menyenangkan dalam mengubah tingkah laku.

Berdasarkan fenomena tersebut maka peneliti tertarik untuk membantu peserta didik meningkatkan kepercayaaan diri dengan menggunakan layanan 
bimbingan kelompok, sedangkan teknik pendekatan konselingnya menggunakan pendekatan konseling behavioral.

\section{METODE}

Subyek penelitian adalah peserta didik kelas VII E tahun pelajaran 20162017 yaitu 10 peserta didik karena berdasarkan hasil observasi awal menunjukkan tingkat kepercayaan diri yang terbilang kurang dari kelas lain. Waktu penelirian dilakukan selama tiga bulan yaitu dari bulan September sampai Novemeber tahun 2016.

Prosedur penelitian ini menggunakan tahapan dalam penelitian tindakan yaitu : (1) Perencanaan, (2) Pelaksanaan, (3) pengamatan, (4) Refleksi (Arikunto, 2006:97). Instrumen penelitian ini menggunakan lembar observasi dan skala kepercayaan diri. Data yang diperoleh dianalisis dengan menggunakan deskriptif. Sedangkan observasi dengan analisis menggunakan teknik presentase untuk melihat kecenderungan yang terjadi dalam bimbingan kelompok. Indikator kinerja dalam penelitian ini berupa peningkatan kepercayaan diri peserta didik yang dianalisis untuk mengetahui ada tidaknya peningkatan kepercayaan diri peserta didik melalui bimbingan kelompok dengan teknik konseling behavior.

\section{HASIL DAN PEMBAHASAN}

\section{Gambaran Kepercayaan Diri Sebelum Diberikan Layanan Bimbingan Kelompok}

Skala kepercayaan diri diberikan (Pre Test) kepada peserta didik kelas VII E sejumlah 39 peserta didik, diperoleh hasil kondisi awal kepercayaan diri peserta didik sebanyak 9 orang berada pada kategori sangat tinggi (presentase 85\%-100\%), 15 orang berada pada kategori tinggi (70\%-84\%), 13 orang berada pada kategori sedang (55\%-69\%), dan 2 orang berada pada kategori rendah (presentase antara $40 \%-54 \%)$.

Hasil Pre Test kepercayaan diri dengan teknik behavior ada 2 orang peserta didik yang masuk kategori rendah, oleh karena itu perlu adanya upaya untuk meningkatkan kepercayaan diri melalui layanan bimbingan kelompok. Adapun 
anggota layanan bimbingan kelompok dalam penelitian ini adalah 8 orang peserta didik yang memiliki kepercayaan diri sedang (VTA, CE, FAD, SR, DK, MZM, MJ, GA), dan 2 orang peserta didik yang memiliki kepercayaan diri rendah (AMA,MP).

Tabel 1. Hasil Analisis Observasi Kepercayaan Diri Sebelum diberikan Layanan Bimbingan Kelompok

\begin{tabular}{|c|c|c|c|c|}
\hline No. & Anggota & Jumlah & Persentase & Kriteria \\
\hline 1 & VTA & 23 & $63,9 \%$ & Sedang \\
\hline 2 & CE & 24 & $66,7 \%$ & Sedang \\
\hline 3 & FAD & 23 & $63,9 \%$ & Sedang \\
\hline 4 & SR & 22 & $61,1 \%$ & Sedang \\
\hline 5 & DK & 23 & $63,9 \%$ & Sedang \\
\hline 6 & MZM & 24 & $66,7 \%$ & Sedang \\
\hline 7 & MJ & 22 & $61,1 \%$ & Sedang \\
\hline 8 & GA & 22 & $61,1 \%$ & Sedang \\
\hline 9 & AMA & 17 & $47,2 \%$ & Rendah \\
\hline 10 & MP & 19 & $52,8 \%$ & Rendah \\
\hline
\end{tabular}

Gambaran Kepercayaan Diri Dengan Teknik Behavior Setelah Diberikan Layanan Bimbingan Kelompok

\section{Siklus 1}

Pada tahap perencanaan, peneliti melakukan beberapa hal antara lain sebagai berikut: a) Pertemuan diadakan sebanyak dua kali pertemuan dengan setiap pertemuan berdurasi lebih 45 menit atau sesuai kebutuhan, b)Mengatur tempat dan teknis penyelenggaraan layanan bimbingan kelompok, c) Layanan bimbingan kelompok dilaksanakan di mushola SMP Negeri 10 Pontianak, d) Menyiapkan kelengkapan administrasi pendukung penelitian. Kelengkapan administrasi tersebut antara lain alat tulis, presensi anggota, format penelitian, pedoman observasi dan laiseg bimbingan kelompok.

Peneliti memberikan layanan bimbingan kelompok melalui teknik konseling behavior sebanyak dua kali pertemuan pada siklus 1 secara rinci adalah sebagai berikut a) Pada pertemuan satu, peneliti memberikan materi tentang bersikap optimis, tujuan dari pemberian materi ini agar peserta didik pentingnya bersikap optimis dan dari optimis kita akan menjadi sukses. Pada pertemuan ke dua diberikan materi tentang pribadi mandiri, tujuan dari pemberian materi ini agar peserta didik dapat menjadi pribadi mandiri yang baik: b) Peneliti menerima 
kehadiran secara terbuka dan mengucapkan terimakasih, memimpin doa, menjelaskan pengertian dan tujuan bimbingan kelompok, menjelaskan cara pelaksanaan bimbingan kelompok, membuat kesepakatan waktu, perkenalan dan permainan, menjelaskan kembali kegiatan bimbingan kelompok, menanyakan kesiapan kelompok untuk melanjutkankegiatan, mengenali suasana kelompok, tentang kesiapan kelompok terlihat masih banyak peserta didik yang belum siap dan mengatasai masalah yang muncul dari kelompok, menanyakankembali kesiapan anggota kelompok, mengemukakan topik bimbingan kelompok, tanya jawab tentang hal-hal yang belum jelas menyangkut topik yang dikemukakan, membahas topik secara mendalam dan tuntas, penyimpulan, menjelaskan bahwa bimbingan layanan kelompok akan diakhiri, menanyakan kesan-kesan kepada anggota kelompok, pembahasana kegiatan lanjutan dan mengucapkan terima kasih.

Pada pertemuan 1 Peneliti dibantu mahasiswa ppl melakukan observasi melalui pengamatan selama kegiatan berlangsung dengan pedoman observasi, dan memberi lembar evaluasi materi bimbingan kelompok. Ada beberapa anggota yang masih belum memahami dengan baik. Hasil pengamtaan melalui pedoman observasi yang peneliti peroleh selama kegiatan yaitu hanya anggota yang memiliki presentase kepercayaan diri tinggi dan sedang saja yang aktif mengeluarkan pendapat, sementara anggota lainnya tertutup dan diam. Dan pertemuan 2 hasil pengamatannya Observasi melalui pengamatan selama kegiatan berlangsung dengan pedoman observasi, dan memberi lembar evaluasi materi bimbingan kelompok untuk mengetahui sejauh mana penyerapan materi. Anggota memahami dengan baik materi bimbingan kelompok. Hasil pengamatan melalui pedoman observasi yang peneliti peroleh selama kegiatan yaitu semua anggota dapat mengeluarkan pendapat.

Secara keseluruhan, pemberian tindakan yang dilakukan terhadap 8 peserta didik yang memiliki kepercayaan diri sedang (VTA, CE, FAD, SR, DK, MZM, MJ, GA) dan 2 orang peserta didik yang memiliki kepercayaan diri rendah (AMA,MP) berjalan dengan baik. Meskipun pada awal kegiatan bimbingan kelompok bagi peserta didik yang memiliki presentase kepercayaan diri sedang sedikit aktif dibandingkan dengan peserta didik yang mempunyai presentase kepercayaan diri 
rendah. Hal ini disebabkan peneliti tidak pernah berhenti untuk berusaha membuat peserta didik yang memiliki presentase kepercayaan diri rendah merasa nyaman dan selalu memberi motivasi sehingga peserta didik menjadi nyaman, terbuka, sukarela, santai dan partisipatif dalam mengikuti kegiatan bimbingan kelompok.

Pada siklus 1 adanya permainan menjadikan anggota ramai dan waktu terbuang sia-sia. Anggota AMA dan MP cenderung diam, belum sepenuhnya terbuka, belum sepenuhnya sukarela dan masih malu-malu dalam menyampaikan pendapat. Setelah siklus pertama terlaksana dengan $2 \mathrm{x}$ pertemuan dan kemudian dilaksanakan Post Test.

\section{Siklus 2}

Pada tahap perencanaan, peneliti melakukan beberapa hal antara lain sebagai berikut: a) Pertemuan diadakan sebanyak dua kali pertemuan dengan setiap pertemuan berdurasi lebih 45 menit atau sesuai kebutuhan, b)Mengatur tempat dan teknis penyelenggaraan layanan bimbingan kelompok, c) Layanan bimbingan kelompok dilaksanakan di ruang BK dan mushola SMP Negeri 10 Pontianak, d) Menyiapkan kelengkapan administrasi pendukung penelitian. Kelengkapan administrasi tersebut antara lain alat tulis, presensi anggota, format penelitian, pedoman observasi dan laiseg bimbingan kelompok

Peneliti memberikan layanan bimbingan kelompok melalui teknik konseling behavior sebanyak dua kali pertemuan pada siklus 2 secara rinci adalah sebagai berikut : pada pertemuan satu, peneliti memberikan materi tentang berfikir dan bersifat positif, tujuan dari pemberian materi ini agar peserta didik dapat berfikir positif karena baik untuk diirnya. Pada pertemuan ke dua diberikan materi tentang perilaku asertif, tujuan dari pemberian materi ini agar peserta didik dapat mengungkapkan perasaannya dengan baik tanpa melukai perasaan orang lain; b) Peneliti menerima kehadiran secara terbuka dan mengucapkan terimakasih, memimpin doa, menjelaskan pengertian dan tujuan bimbingan kelompok, menjelaskan cara pelaksanaan bimbingan kelompok, membuat kesepakatan waktu, perkenalan dan permainan, menjelaskan kembali kegiatan bimbingan kelompok, menanyakan kesiapan kelompok untuk melanjutkankegiatan, mengenali suasana 
kelompok, tentang kesiapan kelompok terlihat masih banyak peserta didik yang belum siap dan mengatasai masalah yang muncul dari kelompok, menanyakankembali kesiapan anggota kelompok, mengemukakan topik bimbingan kelompok, tanya jawab tentang hal-hal yang belum jelas menyangkut topik yang dikemukakan, membahas topik secara mendalam dan tuntas, penyimpulan, menjelaskan bahwa bimbingan layanan kelompok akan diakhiri, menanyakan kesan-kesan kepada anggota kelompok, pembahasana kegiatan lanjutan dan mengucapkan terima kasih.

Pada pertemuan 1 hasil pengamatan Peneliti melakukan observasi melalui pengamatan selama kegiatan berlangsung dengan pedoman observasi, dan memberi lembar evaluasi materi bimbingan kelompok untuk mengetahui sejauh mana penyerapan materi. Hasil pengamatan melalui pedoman observasi yang peneliti peroleh selama kegaitan yaitu semua anggota memperhatikan, sukarela dan aktif mengeluarkan pendapat. Dan pada pertemuan 2 Peneliti melakukan observasi melalui pengamatan selama kegiatan berlangsung dengan pedoman observasi, dan memberi lembar evaluasi

Secara keseluruhan, pemberian tindakan yang dilakukan terhadap 8 peserta didik yang memiliki kepercayaan diri Tinggi (VTA, CE, FAD, SR, DK, MZM, MJ, dan GA), 2 peserta didik yang memiliki kepercayaan diri sedang (AMA dan MP) berjalan dengan baik. Kesepuluh anggota mampu mengikuti kegiatan bimbingan kelompok dengan baik dari awal sampai akhir. Dalam pelaksanaan konseling kedua ini, peneliti tidak menemukan kendala yang berarti.

Melalui pemberian tindakan bimbingan kelompok kepercayaan diri dalam proses ini mengalami peningkatan. Hal ini dapat dilihat dari hasil Post Test kepercayaan diri dan hasil analisis observasi yang telah dilaksanakan.

Tabel 2 : Hasil Pre Test dan Post test kepercayaan Diri Dalam Bimbingan Kelompok

\begin{tabular}{|c|c|c|c|c|c|c|c|c|c|c|}
\hline \multirow[b]{2}{*}{ No. } & \multirow[b]{2}{*}{$\begin{array}{c}\text { Nam } \\
\mathbf{a}\end{array}$} & \multicolumn{3}{|c|}{ Kondisi Awal } & \multicolumn{3}{|c|}{ Siklus 1} & \multicolumn{3}{|c|}{ Siklus 2} \\
\hline & & $\begin{array}{c}\mathbf{J m l} \\
\mathbf{h}\end{array}$ & $\%$ & $\begin{array}{c}\text { Kriteri } \\
\text { a }\end{array}$ & $\begin{array}{c}\mathbf{J m l} \\
\mathbf{h}\end{array}$ & $\%$ & $\begin{array}{c}\text { Kriteri } \\
\text { a }\end{array}$ & $\begin{array}{c}\mathbf{J m l} \\
\mathbf{h}\end{array}$ & $\%$ & $\begin{array}{c}\text { Kriteri } \\
\mathbf{a}\end{array}$ \\
\hline 1. & VTA & 53 & $66,25 \%$ & Sedang & 58 & $\begin{array}{c}72,5 \\
\%\end{array}$ & Tinggi & 65 & $\begin{array}{c}81,25 \\
\%\end{array}$ & Tinggi \\
\hline 2. & $\mathrm{CE}$ & 53 & $66,25 \%$ & Sedng & 60 & $75 \%$ & Tinggi & 66 & $82,5 \%$ & Tinggi \\
\hline
\end{tabular}




\begin{tabular}{|c|c|c|c|c|c|c|c|c|c|c|}
\hline 3. & FAD & 53 & $66,25 \%$ & Sedang & 59 & $\begin{array}{c}73,75 \\
\%\end{array}$ & Tinggi & 67 & $\begin{array}{c}83,75 \\
\%\end{array}$ & Tinggi \\
\hline 4. & SR & 54 & $67,5 \%$ & Sedang & 56 & $70 \%$ & Tinggi & 63 & $\begin{array}{c}78,75 \\
\%\end{array}$ & Tinggi \\
\hline 5. & DK & 54 & $67,5 \%$ & Sedang & 57 & $\begin{array}{c}71,25 \\
\%\end{array}$ & Tinggi & 67 & $\begin{array}{c}83,75 \\
\%\end{array}$ & Tinggi \\
\hline 6. & MZM & 54 & $67,5 \%$ & Sedang & 56 & $70 \%$ & Tinggi & 63 & $\begin{array}{c}78,75 \\
\%\end{array}$ & Tinggi \\
\hline 7. & MJ & 54 & $67,5 \%$ & Sedang & 56 & $70 \%$ & Tinggi & 63 & $\begin{array}{c}78,75 \\
\%\end{array}$ & Tinggi \\
\hline 8. & GA & 55 & $68,75 \%$ & Sedang & 56 & $70 \%$ & Tinggi & 63 & $\begin{array}{c}78,75 \\
\%\end{array}$ & Tinggi \\
\hline 9. & AMA & 43 & $53,75 \%$ & Rendah & 54 & $\begin{array}{c}67,5 \\
\%\end{array}$ & Sedang & 61 & $\begin{array}{c}76,25 \\
\%\end{array}$ & Tinggi \\
\hline 10 & MP & 43 & $53,75 \%$ & Rendah & 55 & $\begin{array}{c}68,75 \\
\%\end{array}$ & Sedang & 60 & $\begin{array}{c}75 \% \\
.\end{array}$ &
\end{tabular}

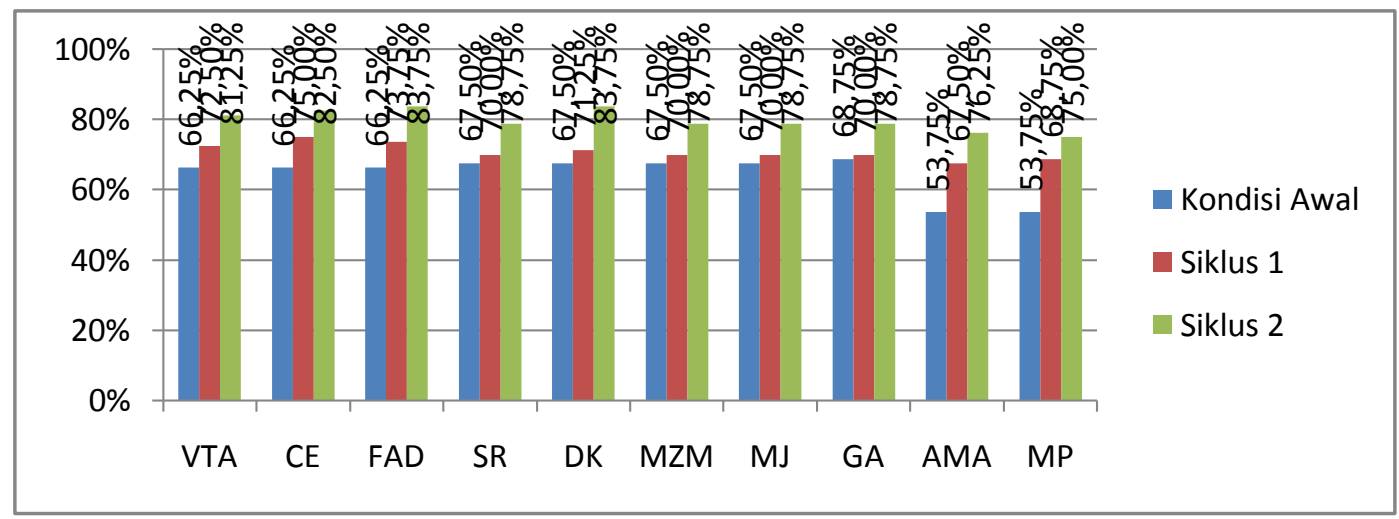

\section{Gambar 1. Hasil Pre Test dan Post Test Kepercayaan Diri Dalam Bimbingan Kelompok}

Hasil Post Test pada siklus 1 menunjukkan bahwa ada peningkatan kepercayaan diri peserta didik dari kondisi awal. Peserta didik yang mempunyai kepercayaan diri sedang dengan presentase VTA 72,5\%, presentase CE 75\%, presentase FAD 73,75\%, presentase SR 70\%, presentase DK 71,25\%, presentase MZM 70\%, presentase MJ 70\%, presentase GA 70\% masuk dalam kategori tinggi. dan peserta didik yang mempunyai kepercayaan diri rendah dengan presentase AMA 67,5\%, MP 68,75\% masuk dalam kategori sedang.

Sedang pada siklus 2 hasil Post Test menunjukkan bahwa ada peningkatan kepercayaan peserta didik. Hasil Post Test menunjukkan bahwa anggota yang mempunyai kepercayaan diri tinggi presentase VTA 81,25\%, presentase CE 82,5\%, presentase FAD 83,75\%, presentase SR 78,75\%, presentase DK 83,75\%, presentase 
MZM 78,75\%, presentase MJ 78,75\%, presentase GA 78,75\%, presentase AMA $76,25 \%$, presentase MP $75 \%$.

Sementara itu hasil analisis observasi pada siklus I (pertemuan 1 dan 2) menunjukkan bahwa anggota yang mempunyai kepercayaan diri sedang dan rendah presentasenya bertambah (presentase VTA naik 5,6\%, presentase CE naik 2,7\%, presentase FAD naik 5,5\%, presentase SR naik 5,6\%, presentase DK naik 5,5\%, presentase MZM naik 5,6\%, presentase MJ naik 5,6\%, presentase GA naik 5,5\%, presentase AMA naik 11,2\%, presentase MP naik 8,9\% masuk dalam kategori tinggi.

Sedang pada siklus 2 hasil analisis observasi menunjukkan bahwa ada peningkatan kepercayaan peserta didik. Hasil analisis observasi menunjukkan bahwa anggota yang mempunyai kepercayaan diri tinggi (dari pertemuan 1 ke pertemuan 2) ada yang meningkat dan ada yang tetap. Presentase VTA tetap 80,3\%, presentase CE tetap $83 \%$, presentase FAD tetap 83,3\%, presentase SR naik 2,8\%, presentase DK naik 2,8\%, presentase MZM naik 2,7\%, presentase MJ tetap 80,5\%, presentase GA naik 2,8\%, presentase AMA tetap 77,8\%, dan presentase MP tetap $75 \%$ masuk dalam kategori tinggi.

Tabel 3. Hasil Analisis Observasi Kepercayaan Diri Dalam Bimbingan Kelompok (Kondisi Sebelum diberikan Layanan Bimbingan Kelompok)

\begin{tabular}{|c|c|c|c|c|}
\hline No. & Anggota & Jumlah & Presentase & Kriteria \\
\hline 1 & VTA & 23 & $63,9 \%$ & Sedang \\
\hline 2 & CE & 24 & $66,7 \%$ & Sedang \\
\hline 3 & FAD & 23 & $63,9 \%$ & Sedang \\
\hline 4 & SR & 22 & $61,1 \%$ & Sedang \\
\hline 5 & DK & 23 & $63,9 \%$ & Sedang \\
\hline 6 & MZM & 24 & $66,7 \%$ & Sedang \\
\hline 7 & MJ & 22 & $61,1 \%$ & Sedang \\
\hline 8 & GA & 22 & $61,1 \%$ & Sedang \\
\hline 9 & AMA & 17 & $47,2 \%$ & Rendah \\
\hline 10 & MP & 19 & $52,8 \%$ & Rendah \\
\hline
\end{tabular}

Tabel 4. Kondisi Setelah diberikan Layanan Bimbingan Kelompok (Siklus I)

\begin{tabular}{|l|c|c|c|c|c|c|c|}
\hline \multirow{2}{*}{ No. } & Anggota & \multicolumn{5}{|c|}{ Siklus I } \\
\cline { 3 - 7 } & & \multicolumn{3}{|c|}{ Pertemuan 1 } & \multicolumn{3}{c|}{ Pertemuan 2 } \\
\cline { 3 - 7 } & & Jumlah & $\%$ & Kriteria & Jumlah & $\%$ & Kriteria \\
\hline
\end{tabular}




\begin{tabular}{|c|c|c|c|c|c|c|c|}
\hline 1 & VTA & 26 & $72,2 \%$ & Tinggi & 28 & $77,8 \%$ & Tinggi \\
\hline 2 & CE & 28 & $77,8 \%$ & Tinggi & 29 & $80,5 \%$ & Tinggi \\
\hline 3 & FAD & 27 & $75 \%$ & Tinggi & 29 & $80,5 \%$ & Tinggi \\
\hline 4 & SR & 26 & $72,2 \%$ & Tinggi & 28 & $77,8 \%$ & Tinggi \\
\hline 5 & DK & 27 & $75 \%$ & Tinggi & 29 & $80,5 \%$ & Tinggi \\
\hline 6 & MZM & 26 & $72,2 \%$ & Tinggi & 28 & $77,8 \%$ & Tinggi \\
\hline 7 & MJ & 26 & $72,2 \%$ & Tinggi & 28 & $77,8 \%$ & Tinggi \\
\hline 8 & GA & 27 & $75 \%$ & Tinggi & 29 & $80,5 \%$ & Tinggi \\
\hline 9 & AMA & 23 & $63,8 \%$ & Sedang & 27 & $75 \%$ & Tinggi \\
\hline 10 & MP & 23 & $63,8 \%$ & Sedang & 26 & $72,2 \%$ & Tinggi \\
\hline
\end{tabular}

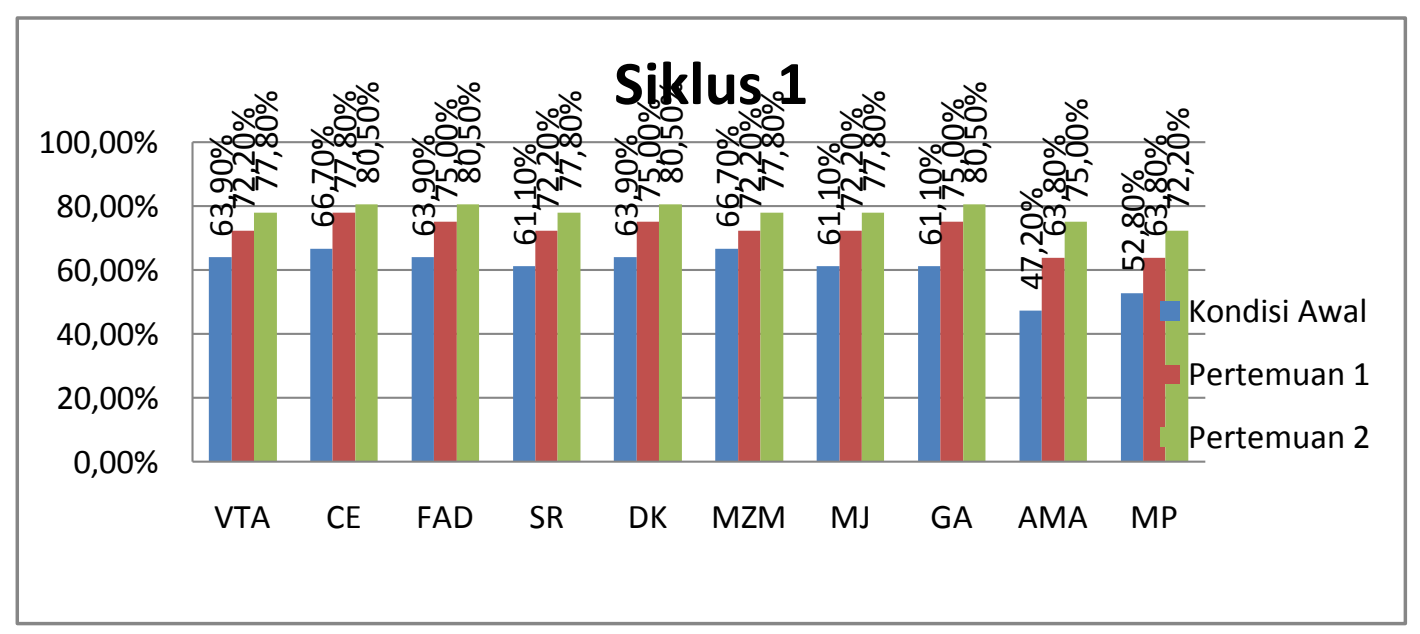

Gambar 2. Grafik Hasil Analisis Observasi Kepercayaan Diri Dalam Bimbingan Kelompok

Tabel 5. Kondisi Setelah diberikan Layanan Bimbingan Kelompok (Siklus 2)

\begin{tabular}{|c|c|c|c|c|c|c|c|}
\hline \multirow{2}{*}{ No. } & \multirow{2}{*}{ Anggota } & \multicolumn{6}{|c|}{ Siklus 2 } \\
\cline { 3 - 8 } & & \multicolumn{3}{|c|}{ Pertemuan 1 } & \multicolumn{3}{c|}{ Pertemuan 2 } \\
\cline { 3 - 8 } & & Jumlah & $\mathbf{\%}$ & Kriteria & Jumlah & $\mathbf{\%}$ & Kriteria \\
\hline 1 & VTA & 30 & $80,3 \%$ & Tinggi & 30 & $80,3 \%$ & Tinggi \\
\hline 2 & CE & 31 & $86,1 \%$ & Tinggi & 31 & $86,1 \%$ & Tinggi \\
\hline 3 & FAD & 30 & $83,3 \%$ & Tinggi & 30 & $83,3 \%$ & Tinggi \\
\hline 4 & SR & 29 & $80,5 \%$ & Tinggi & 30 & $83,3 \%$ & Tinggi \\
\hline 5 & DK & 30 & $83,3 \%$ & Tinggi & 31 & $86,1 \%$ & Tinggi \\
\hline 6 & MZM & 28 & $77,8 \%$ & Tinggi & 29 & $80,5 \%$ & Tinggi \\
\hline 7 & MJ & 29 & $80,5 \%$ & Tinggi & 29 & $80,5 \%$ & Tinggi \\
\hline 8 & GA & 29 & $80,5 \%$ & Tinggi & 30 & $83,3 \%$ & Tinggi \\
\hline 9 & AMA & 28 & $77,8 \%$ & Tinggi & 28 & $77,8 \%$ & Tinggi \\
\hline 10 & MP & 27 & $75 \%$ & Tinggi & 27 & $75 \%$ & Tinggi \\
\hline
\end{tabular}




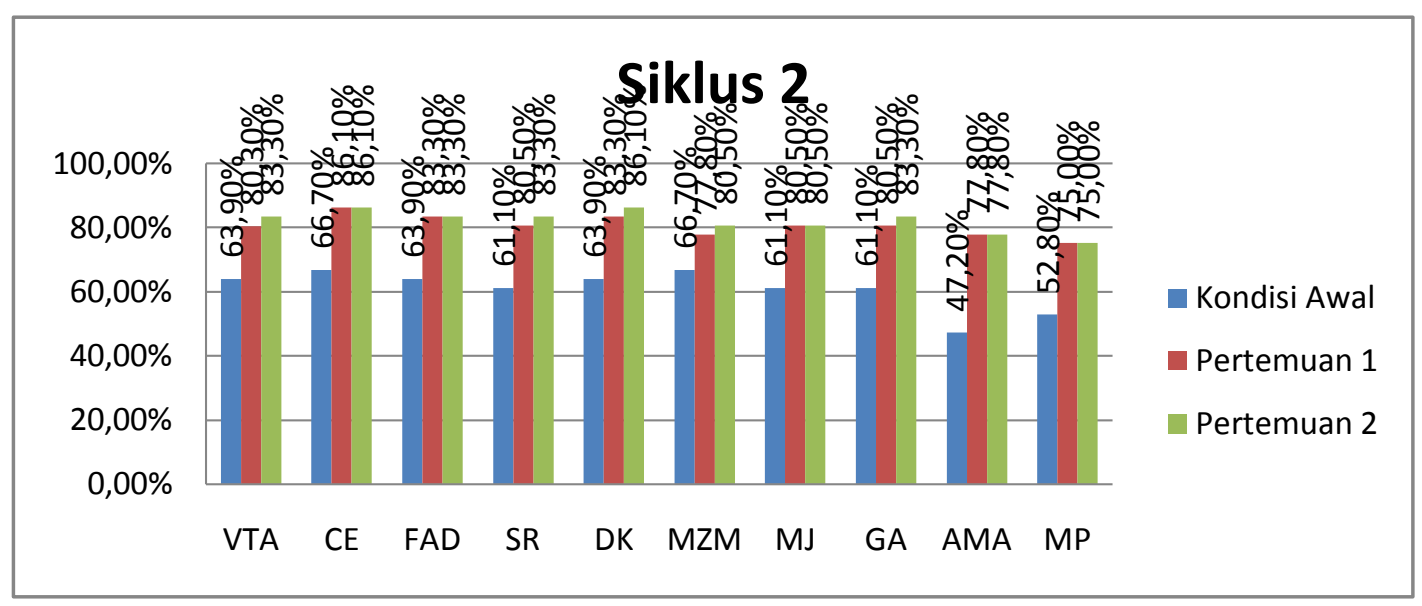

\section{Gambar 3. Grafik Hasil Analisis Observasi kepercayaan Diri dalam Bimbingan Kelompok}

\section{Pembahasan}

Data awal (Pre Test) secara keseluruhan sejumlah 39 peserta didik sebanyak 9 orang berada pada kategori sangat tinggi (presentase 85\%-100\%), 15 orang berada pada kategori tinggi $(70 \%-84 \%), 13$ orang berada pada kategori sedang (55\%-69\%), dan 2 orang berada pada kategori rendah (presentase antara 40\%54\%). Hasil data awal tersebut diambil subyek 10 peserta didik dari kategori sedang dan rendah selanjutnya diberikan tindakan berupa bimbingan kelompok. Diperoleh 8 orang peserta didik dengan kepercayaan diri sedang, dan 2 orang peserta didik dengan kepercayaan diri rendah. Kemudian peneliti memberikan bimbingan kelompok kepada anggota yang sudah dibentuk. Alasan peneliti memberikan bimbingan kelompok pada peserta didik kelas VII E SMP Negeri 10 Pontianak yaitu agar kepercayaan diri dapat meningkat kearah lebih baik.

Upaya untuk meningkatkan kepercayaan diri melalui layanan bimbingan kelompok dilakukan tindakan sebayak 4 kali pertemuan (4 topik tugas) dalam 2 siklus (siklus 1 dan siklus 2). Pada masing-masing siklus melalui empat tahapan yaitu tahap perencanaan, tindakan, observasi, dan refleksi. Peningkatan kepercayaan diri dapat diketahui dari hasil analisis skala kepercayaaan diri setiap akhir siklus.

Setelah diberikan layanan bimbingan kelompok pada siklus 1 diperoleh peningkatan hasil Post Test kepercayaan diri dari kondisi awal. Diperoleh 8 orang 
peserta didik dengan kepercayaan diri tinggi bertambah dari 70\%-72,5\% masuk dalam kategori tinggi, dan 2 orang peserta didik dengan kepercayaan diri rendah bertambah 67,5\%-68,78\% masuk dalam kategori sedang. Hasil observasi juga menunjukkan adanya peningkatan kepercayaan diri. Pada pertemuan pertama siklus 1 dalam kegiatan bimbingan kelompok peneliti mengajak anggota untuk mendiskusikan topik bersikap optimis dalam hidup. Anggota yang mempunyai kepercayaan diri sedang cendrung santai, terbuka, aktif, dan sukarela dalam menyampaikan pendapat. Sedang anggota yang mempunyai presentase kepercayaan diri rendah (AMA dan MP) pada tidakan bimbingan kelompok cendrung diam, malu-malu, sesekali melirikkan matanya ke teman sebelah. Bahkan pada saat mengeluarkan pendapat / tanggapan menunggu diminta pemimpin kelompok terlebih dahulu.

Pada siklus 2 peneliti melakukan bimbingan kelompok sebanyak 2 kali pertemuan. Diperoleh 8 peserta didik dengan presentase kepercayaan diri sedang bertambah $83,75 \%$ masuk dalam kategori tinggi, dan 2 orang peserta didik dengan presentase kepercayaan diri rendah bertambah 76,25\% masuk dalam kategori tinggi sehingga pada siklus 2 skala kepercayaan diri untuk 10 orang peserta didik masuk dalam kategori tinggi.

Hasil observasi pada siklus 2 menunjukkan adanya peningkatan bahwa 10 orang peserta didik dengan kepercayaan sedang dan rendah mengalami perubahan dimana peserta didik dapat menunjukkan adanya perubahan sikap menjadi lebih aktif dalam berpartisipasi, sukarela (mengeluarkan pendapat tanpa diminta pemimpin kelompok terlebih dahulu walaupun jawabannya hanya seperlunya saja) dan terbuka. Seperti yang dikemukakan oleh Surya bahwa "Rasa percaya diri merupakan sikap mental optimis dari kesanggupan anak terhadap kemampuan diri untuk menyelesaikan segala sesuatu dan kemampuan diri untuk melakukan penyesuaian diri pada situasi yang dihadapi (Surya, 2007:56).

\section{SIMPULAN}

1. Perancang pelaksana kegiatan bimbingan kelompok tentang kepercayaan diri dengan teknik behavior pada peserta didik kelas VII E SMP Negeri 10 
Pontianak pada awal sebelum diberikan layanan bimbingan kelompok terdapat 8 orang peserta didik yang memiliki kepercayaan diri dengan presentase sedang $68,75 \%$ dan peserta didik yang mempunyai kepercayaan diri rendah 53,75\%. Hasil observasi kepercayaan diri peserat didik sebelum diberikan layanan bimbingan kelompok dengan kategori sedang 66,7\% dan hasil observasi peserta didik rendah $52,8 \%$.

2. Pelaksanaan tindakan kegiatan bimbingan kelompok tentang kepercayaan diri dengan teknik behavior pada peserta didik kelas VII E SMP Negeri 10 Pontianak pada siklus 1 kepercayaan diri peserta didik dengan presentase sedang mengalami peningkatan $70 \%-72,75 \%$ masuk dalam kategori presentase tinggi dan peserta didik dengan kepercayaan diri rendah bertambah 67,75\%-68,78\% masuk dalam kategori presentase sedang. Selanjutnya dari hasil observasi pada peserta didik pada siklus 1 menunjukkan peningkatan dari pertemuan 1 ke pertemuan 2. Presentase VTA dari 72,2\% menjadi 77,8\%, presentase CE dari $77,8 \%$ menjadi $80,5 \%$, presentase FAD dari $75 \%$ menjadi $80,5 \%$, presentase SR dari $72,2 \%$ menjadi $71,8 \%$, presentase DK dari $75 \%$ menjadi $80,5 \%$, presentase MZM dari 72,2\% menjadi 77,8\%, presentase MJ dari 72,2\% menjadi 77,8\% dan presentase GA dari $75 \%$ menjadi $80,5 \%$ ) masuk dalam kategori presentase kepercayaaan diri tinggi. Anggota yang mempunyai kepercayaan diri rendah presentase peningkatan kepercayaan diri bertambah (presentase AMA dari $63,8 \%$ menjadi $75 \%$, dan presentase MP dari $67,8 \%$ menjadi $72,7 \%$ ) masuk dalam kategori presentase kepercayaaan diri sedang.

3. Hasil siklus 2 hasil Post Test menunjukkan bahwa ada peningkatan kepercayaan peserta didik. Hasil Post Test menunjukkan bahwa anggota yang mempunyai kepercayaan diri sedang presentase VTA 81,25\%, presentase CE 82,5\%, presentase FAD 83,75\%, presentase SR 78,75\%, presentase DK 83,75\%, presentase MZM 78,75\%, presentase MJ 78,75\%, presentase GA 78,75\%, presentase AMA 76,25\%, presentase MP 75\% masuk dalam kategori presentase tinggi. Hasil analisis observasi menunjukkan bahwa anggota yang mempunyai kepercayaan diri tinggi (dari pertemuan 1 ke pertemuan 2) ada yang meningkat dan ada yang tetap. Presentase VTA tetap 80,3\%, presentase CE tetap 83\%, 
presentase FAD tetap 83,3\%, presentase SR naik 2,8\%, presentase DK naik 2,8\%, presentase MZM naik 2,7\%, presentase MJ tetap 80,5\%, presentase GA naik 2,8\%, presentase AMA tetap 77,8\%, dan presentase MP tetap 75\% masuk dalam kategori tinggi. Hasil post-test menunjukkan terjadi peningkatan pengetahuan peserta didik tentang kepercayaan diri, pada siklus 1 diberikan post-test kepada peserta didik dengan hasil kategori tinggi dan sedang untuk peserta didik dengan kepercayaan diri sedang dan rendah. Pada siklus 2 diberikan post-test kepada peserta didik dengan hasil kategori tinggi untuk peserta didik dengan kepercayaan diri sedang dan rendah. Artinya dapat dilihat bahwa pengetahuan awal peserta didik pada pra siklus, mengalami peningkatan yang tinggi setelah mendapat materi mengenai kepercayaan diri pada akhir kegiatan siklus 2 .

\section{DAFTAR PUSTAKA}

Abdurrakhman Gintings. 2010. Esensi Praktis Belajar dan Pembelajaran, Disiapkan untuk Pendidikan Profesi dan Sertifikasi Guru - Dosen. Bandung: Humaniora

Anita, Lie. 2003. 101 Cara Menumbuhkan Percaya Diri Anak. Jakarta: Elix Media Komputindo.

Arikunto, S. 2006. Prosedur Penelitian (Suatu pendekatan Praktik). Jakarta: Rineka Cipta.

Azwar, S. 2006. Penyusunan Skala Psikologi. Yogyakarta: Pustaka Pelajar.

Corey, Gerald. 1995. Teori dan Praktek Konseling dan Psikoterapi vol 4. Translated by Drs Mulyarto. Semarang: IKIP Semarang Press.

2005. Teori dan Praktek Konseling dan Psikoterapi. Bandung: Refika Aditama.

Das Salirawati. 2012. "Percaya Diri, Keingintahuan, dan Berjiawa Wirausaha: Tiga Karakter Penting Bagi Peserta Didik". Jurnal Pendidikan Karakter. Vol. 2. No. 11. Hlm. 218-219.

Djiwandono, Sri Esti Wuryani. 2004. Psikologi Pendidikan. Jakarta: Gramedia. 
Hallen A. 2005. Bimbingan dan Konseling Edisi Revisi. Jakarta: Quantum Teaching.

Inge Pudjiastuti A. 2010. "Memperkuat Kepercayaan Diri Anak Melalui Percakapan Referensial". Jurnal Pendidikan Penabur. no 15.

Prayitno. 1995. Layanan Bimbingan Konseling Kelompok (Dasar dan Profil). Jakarta: Ghalila Indonesia.

Prayitno dan Erman Amti. 1994. Dasar-dasar Bimbingan dan Konseling. Jakarta: Rienika Cipta.

Pujosuwarno Sayekti. 1993. Berbagai Pendekatan Dalam Konseling. Yogyakarta: Menara Mas Offset.

Latipun. 2008. Psikologi Konseling. Malang: UMM Pres

Rahkmat, J. 2000. Psikologi Komunikasi rev.ed. Bandung: Remaja Rosdakarya.

Rita Eka Izzaty, dkk. 2008. Perkembangan Peserta Didik. Yogyakarta: UNY Press.

Romlah. 2001. Layanan Bimbingan Kelompok. Jakarta: Rineka Cipta.

Santrock, J.W. 2003. Adolsence. Jakarta: Erlangga.

Sudijono, A. 2008. Pengantar Statistik Pendidikan. Jakarta: Rasa Grafindo Persada.

Sukardi, D.K. 2000. Manejemen Pendidikan. Jakarta: Raja Grafindo.

Surya, H. 2007. Percaya Diri Itu Penting. Jakarta: Gramedia.

Winkel, W.S dan Hastuti, S.N.M. 2006. Bimbingan dan Konseling di Institut Pendidikan. Yogyakarta: Media Abadi. 